\title{
Art and culture: Hong Kong or the creation of a collective memory
}

Gérard Henry

\section{OpenEdition}

1 Journals

Édition électronique

URL : http://journals.openedition.org/chinaperspectives/1763

DOI : 10.4000/chinaperspectives. 1763

ISSN : 1996-4617

Éditeur

Centre d'étude français sur la Chine contemporaine

Édition imprimée

Date de publication : 15 avril 2007

ISSN : 2070-3449

Référence électronique

Gérard Henry, "Art and culture: Hong Kong or the creation of a collective memory », China Perspectives [En ligne], 2007/2 | 2007, mis en ligne le 08 avril 2008, consulté le 28 octobre 2019. URL : http:// journals.openedition.org/chinaperspectives/1763; DOI : 10.4000/chinaperspectives.1763 


\section{Art and Culture: Hong Kong}

\section{or the Creation of a}

\section{Collective Memory}

GÉRARD HENRY

$\square$ iscussion of art and culture in Hong Kong naturally leads to questions concerning Hong Kong's cultural identity, which was the main theme of the cultural debates that preceded and followed the transfer of sovereignty to China. "Identity," in this context, refers to the sum of values, practices and customs shared by an entire population. Questioning cultural identity is not specific to Hong Kong and generally becomes an issue whenever a country or a people feel threatened or overwhelmed by a period of disruption and confusion. Chinese cultural identity as a whole has continually been put into question throughout its confrontation with Western civilization ${ }^{(1)}$. In Hong Kong, the question of identity, explored primarily within artistic and cultural circles, has resulted in a recreation of the past and a larger debate over the necessity to reconstitute collective memory in order to affirm the city's identity better in the face of an uncertain future.

\section{A specific culture under threat}

For Hong Kong, the great shake-up came with the announcement in 1984 of the plan to hand the territory over to China. While a major political disruption, the handover promised to be even more of a social and cultural upheaval since it was not a matter of decolonisation in the traditional sense but of a transformation from a liberal colonial regime to a communist regime, one that was completely foreign to the younger generations while familiar to a significant part of the elder generation that had fled that regime and sought refuge under British colonial protection. Nor was it possible for Hong Kong to return to its pre-colonial culture since before the arrival of the British in 1841, Hong Kong had been little more than a collection of fishing villages, even if there had been a few settlements during the Song Dynasty. For many years the city was a commercial and military port, a trading post where Europeans and Chinese conducted business.
The Second World War and the threat of the Japanese brought an end to this peaceful situation, as the city became a zone of migration, a port of refuge and passage for people heading towards other horizons. Occupied by the Japanese, the city again went on to become a port of destination for a significant migration from the mainland after the proclamation of the People's Republic of China. From this point on, it was physically and culturally cut off from mainland China and was incorporated into a regime of "free trade." The city's identity was grounded in the overriding aim of exporting all that was Made in Hong Kong to markets around the world while the fundamental desire of most of its large immigrant population was to survive, to secure housing, to raise children. While art in the sense of artistic production developed slowly, people in Hong Kong created their own popular culture, a way of living that was different from that of the mainland, with its own leisure activities, and especially its own music and film culture that eventually spread throughout much of Asia. The emergence of this identity through the culture of everyday life was documented in a landmark exhibit curated by Matthew Turner and Oscar Ho of the Hong Kong Art Centre in 1993 called "Hong Kong Sixties, Designing Identity ${ }^{(2)}$."

In 1984, the initial reaction in Hong Kong to the planned handover to China was relatively free of anxiety as Deng Xiaoping's series of reforms seemed promising. But the events of Tiananmen in 1989 hit Hong Kong like a lightening bolt and prompted thousands of people to take to the streets, something most of the protesters had never done before. The slightest rumour and every threat from up north

1. See on this subject Werner Meissner, "China's Search for Cultural and National Identity," China Perspectives, nº 68, September-December 2006, pp. 41-54.

2. Hong Kong Sixties, Designing Identity, illustrated catalogue , 175 pp., edited by Matthew Turner and Irene Ngnan, 1993, Hong Kong Arts Centre. Comprising numerous analytical texts by Matthew Turner, Oscar Ho, Terence Lo and Philippe Robertson. 
caused tremors throughout the city and set off, during the final months, an effervescence that seemed to accelerate, as time seemed to telescope towards the fateful date.

This apprehension was made visible in the work of the plastic artist Oscar Ho, who set out to record through drawings and short texts compiled in an illustrated journal he called Stories around Town the social and political events, customs, legends, random news items, and oddities that captured the attention of people in Hong Kong at that time. One of these drawings, Brotherhood with the Triads, resurrects an infamous statement by the Chinese minister of security that among the gangsters of the triads there were true patriots, a statement that rattled the residents of Hong Kong. Another piece deals with a strange illness affecting the residents of Tuen Mun: "A boulder on the back of the people is growing to the point that it is crushing them to death. In the face of this terrible misfortune, the government has decided to keep all information confidential."

In a parallel series called Happy Hong Kong, Ho uses small drawings of people in pursuit of life's pleasures-betting on horses and frantically having sex-to denounce the contempt with which Beijing perceives the residents of Hong Kong:

One of the most disturbing things is to hear the Chinese government repeat over and over again: "Hey, people of Hong Kong, don't worry, after 97 you will be able to continue dancing and betting on horses!" As if dancing (meaning prostitution), betting, and money were the only intellectual or cultural or spiritual values in Hong Kong ${ }^{(3)}$.

During the years preceding the handover, it was a group of young artists, the Young Artists Association, that most explicitly sketched the framework within which Hong Kong society was evolving ${ }^{(4)}$. In an installation titled "Red Water Zone, 1995" Tsang Wai Hang placed a basin of red water with an electric motor in the middle of a sand pile and in the red water a traditional junk turned round and round. In another installation, "Transition Space, 1995," Kum Chi Keng used the symbol of a bird flying from one cage to another. The image recalled a similar one by Hong Kong's most famous political cartoonist, Zunzi, who, in July 1984, drew a picture of a duck being pushed with a stick out of one cage through a wire tunnel towards another cage where the duck was prodded towards a hand holding a bowl. In each case, the artistic expression explored a limited space that was carefully defined by the Basic Law, Hong Kong's "constitution," which one artist transformed into a golden text placed behind glass, venerated as if it were Hong Kong's new bible. It was a space that precluded both self-determination and escape. In an exhibit called Ac.cul.turation Wong Shun Kit, one of the leaders of the association, presented his vision of post-handover Hong Kong with a little map of the city's labyrinthine streets through which a tiny humanoid robot, the Hong Konger, wandered while dominated by three giants:

These three giants are the three symptoms of an authoritarian political power: destruction, development, discipline. In this sense, China is unstable, what face it will present is unknown ${ }^{(5)}$.

Another installation, called "Floating Identity," captured the city's anxiety concerning 1997. It consisted of a small map of Hong Kong beneath a sky full of foreign flags and little human-shaped kites fluttering about looking for somewhere to land. Should one stay or emigrate to another country? Artists asked themselves the same question. Some, like Raphael Chan, felt like orphans:

Hong Kong seemed to be like a 100-year old orphaned infant, incapable of remembering the face of its parents. It could speak many foreign languages but had completely forgotten its mother tongue [...] and now it was to return home but it feared losing its freedom for within the larger family there were many rules, limits on free speech and no disobeying the elders.

This fear of the future was summed up in Victoria Harbor Wedding Banquet, a theatre piece created by Tang Shu Wing in January 1997 in which he explored the passage from solitude to conjugal life, the intrusion of one person into another's universe which, the author said, "mirrored the political universe of Hong Kong and China, a marriage arranged by the parents ${ }^{(6)}$." Censorship, freedom of speech, problems linked to colonialism, cultural differences between Hong Kong and the mainland are the most recurring themes of the most political artists of this era, but they were not

3. "Oscar Ho, Apocalypse ou fin d'un monde?", Paroles, n 130, December 1994, pp. 11 13.

4. Special Pre 97 Art zone, illustrated catalogue of these artists, Hong Kong, Young Artist Association, Art Development Council, Sun Sai Kei publisher, April 1996.

5. "Wong Shun Kit, Hong Kong, une identité flottante," Paroles, $n^{0}$ 141, June 1996, pp. 16-19.

6. "Noces pour Victoria Harbour," Paroles, $n^{0} 149$, January 1999, pp. 18-19. 


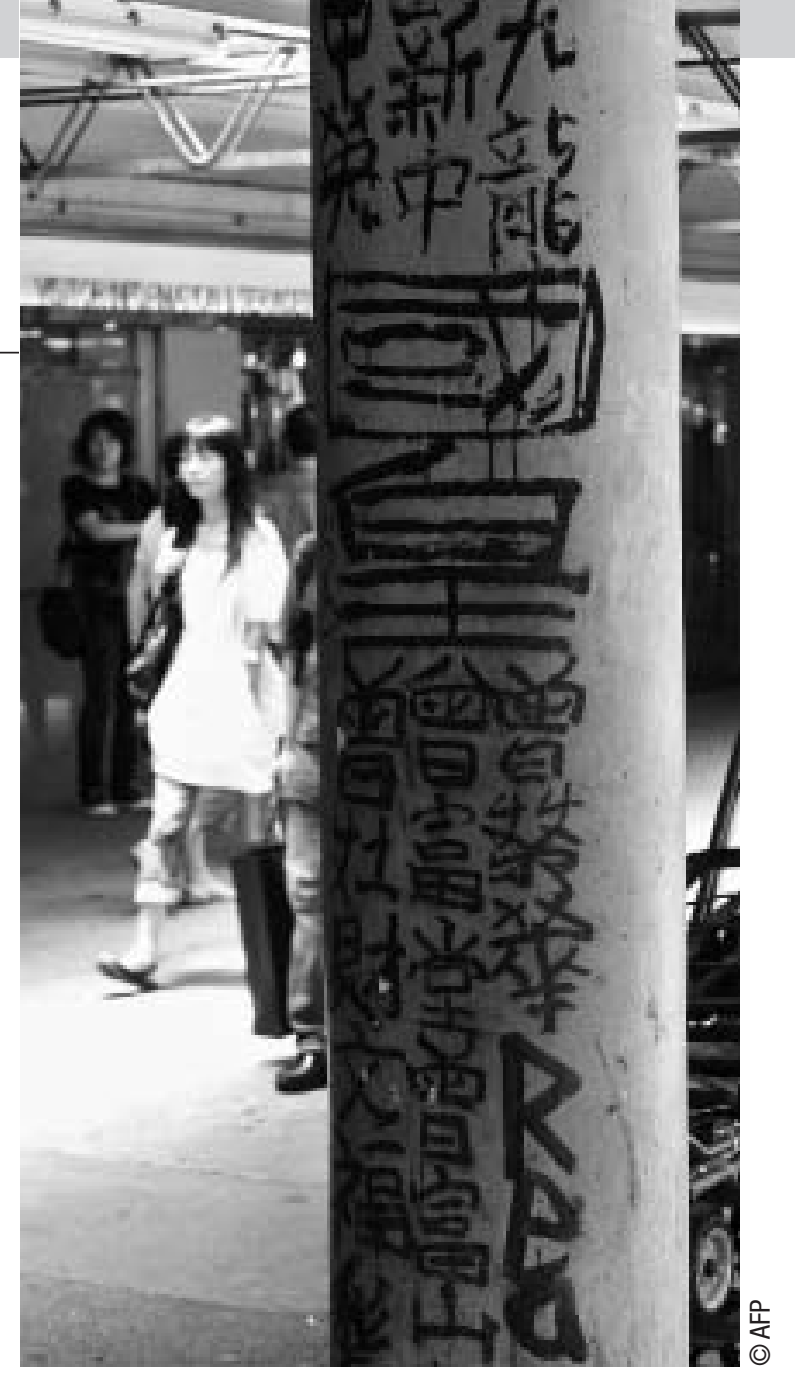
before 1997 made it difficult to have access to a studio. Nevertheless, these artists had a great influence on intellectual and artistic circles of both that period and the years after. Yank Wong Yan-kwai, for example, was with Yeung Tung Leung and Choi Yee Yuen one of the founders of the first artists associations, Quart Society on Aberdeen Street. Closely linked to the major political cartoonists of the Chinese press like Ma Long and Zunzi, they were the driving force behind numerous political protest and pro-democracy movements. Their rebellious spirit infused bars throughout the city, such as Club 64, a bar whose original name, in support of the students of Tiananmen, was a reference to 4 June 1989, until the name changed to Club 71, a reference to the big demonstration of 1 July 2003 in protest against Article 23 of the Basic Law. These places became hangouts for artists, intellectuals, filmmakers, political activists from Hong Kong, China, and overseas, and exerted a powerful attraction over younger generations. The anniversary of 4 June 1989 had a special mobilising effect on these artists who, as an echo to the Goddess of Democracy erected by students in Tiananmen in 1989, created works in commemoration, like the "Goddess of Democracy Stone Wall" in 1999, erected by Yank Wong Yan-kwai and other artists. Following the prompting of the young artist, Leung Po Shan, even a statue called "The Flying Frenchman" by the French artist, César, in front of the Hong Kong Cultural Centre, became the focus of a large gathering on 3 June 1999, at which time the statue was covered with white flow-

ers. The assembly was in response to a persistent rumour that César had allegedly named the work at first "The Freedom Fighter" but, given the political climate of the time, had changed it to the more innocuous "Flying Frenchman ${ }^{(8)}$."

These were also the years in which the first state institutions opened like the Museum of Science, the Museum of Art, several universities and the Art Development Council which plays a key role in developing the art world in Hong Kong through the awarding of grants to several organisations and funding individual projects. In 1993, the exhibit "China New Art, Post 89," which was staged at the Hong Kong Arts Festival and organised by the Hanart Gallery, heralded the arrival of contemporary artists from the mainland to the international scene. Hong Kong provided a gust of oxygen to the Chinese artists and a springboard to the outside world. 1995 was the year of the creation of Para/site, an artists collective which was to play a major role in the artistic scene between 1998 and 2004, prodding it towards new developments. It was at this time that the first Hong Kong artists began to attract attention from abroad.

7. Concerning this period, see David Clarke and Oscar Ho, Someone Else's Story-Our Footnotes. Contemporary Art of Hong Kong (1990-1999), Hong Kong Arts Centre, July 2002.

8. On the subject of the Tiananmen commemorations and the polemic around César, and on art in Hong Kong's public space, see the excellent book by David Clarke, Hong Kong: Art, Culture and Decolonization, Hong Kong, Hong Kong University Press, 2001. See also the interview with César in Paroles, $n^{0}$ 114, April 1993 and Paroles, n 167, July/August 1999. 


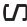

In this general atmosphere, June 1997 came and went without any notable artistic event except perhaps one: on the day that the antique Rolls Royce of the last governor departed for the final time from the governor's residence, taking His Excellency Chris Patten and his family past walls that had been painted pure white all along the route, towards the yacht Britannia, this author saw Tsang Tsou Choi, 76 years old at the time, the most famous graffiti artist in Hong Kong, who calls himself the "King of Kowloon," hobble about with a paint brush and bucket in hand towards Hong Kong's last governor to demand, as he had done repeatedly for 40 years, to be recognised as the Emperor of Kowloon and to demand the return of his land which, in his view, the British Crown had stolen. Without a doubt it was the most poetic gesture marking the last moments of the British Empire in Asia in what otherwise was a day of pouring rain.

\section{From nostalgia to harsh} realism, the other side of Hong Kong identity in film

In the ten years from 1997 to 2007, the world of cinema also went through a series of changes: film pirating, emptying movie theatres, difficulties in obtaining funding. But during this period of crisis two phenomena proved to be noteworthy: the emergence of a new realist and internationally recognised cinema and the influence of the director Wong Kar-wai, who transformed the image of Hong Kong around the world.

Hong Kong's film industry was jeopardised, to a large extent, by the departure for Hollywood of its biggest stars, like the directors John Woo and Tsui Hark, or the actors Chow Yun-Fat and Jackie Chan. Today, however, it is Hollywood, eager to break into the enormous market, that has come to Asia. Columbia, Miramax, $20^{\text {th }}$ Century Fox and Warner Brothers have all opened studios in Hong Kong. The goal: produce Asian superproductions with the Chinese stars established in Hollywood. Columbia was the first out of the starting block when it financed a Hong Kong film directed by Tsui Hark, Tune and Tide, bought the world rights to the last two films by the Chinese director, Zhang Yimou, and co-financed the first Kung Fu film of the Taiwanese Hollywood director, Ang Lee, Crouching Tiger, Hidden Dragon. The Hollywood giants teamed up with Hong Kong production companies, who were already allied with producers from the People's Republic, with the aim of sidestepping the 20-a-year limit on foreign films to penetrate the Chinese market. Thanks to Hollywood, Kung Fu is back in fashion ${ }^{(9)}$.
At the non-commercial level, the Hong Kong International Film Festival (HKIFF), which is no longer under direct government control, and is organised by an independent association, has grown considerably to become a showcase for new Asian films. In 2007, it awarded for the first time its own "Oscars," the AFA (Asia Film Awards) in the hope of gaining greater global recognition for both the festival and Asian cinema. In 1999, the festival had already added to its programme a more creative dimension, with a selection of films called "The Age of Independents" featuring new directors. The goal was to provide support for the directors by allowing them to show their films and break out of their isolation. The subsequent years witnessed, in fact, the takeoff of the career of a growing number of young Hong Kong directors. In this context, it must be added that the Hong Kong Arts Centre organised its first Independent Short Films and Video Awards (IFVA) in 1995, which subsequently revealed the talents of artists like Ramon Hui, who created the animated hero Shrek, the director, Yu Lik Wai, and the now famous Chinese director, Jia Zhangke.

\section{Documentary realism}

These young Hong Kong filmmakers introduced an interesting new genre, the semi-documentary film, which did not exist previously in Hong Kong. They explored their own neighbourhoods, the most ordinary and overlooked aspects, and focused on a whole generation of dropouts, immigrants, and down-and-out characters. One of the most beautiful examples is the first full-length film by Yu Lik Wai, Love Will Tear $U_{s}$ Apart, which was part of the official selection for the Cannes Film Festival of 1999. Four characters, all ne'er-do-wells, find themselves at the margins of post-1997 Hong Kong society despite their dreams of a city where the streets are paved with gold. They manage to survive on what comes their way. Yu Lik Wai takes us through a harsh Hong Kong nightscape where the glare of green, red and blue neon lights contrasts with gloomy, run-down interiors. With the help of music and a host of carefully chosen details, he captures the Hong Kong of immigrants from the mainland at that time and their disillusionment following the handover in 1997 that was celebrated with so much pomp. One image in the film is of the enormous banner that hung from 1997 until well afterwards on the headquarters of the People's Liberation Army facing the water: "Love Hong Kong, Love

9. Cf. Karen Mazurkewitvch, "Hollywood Jumps In," Far Eastern Economic Review, 20 April 2000. 
the Motherland," a slogan never embraced by the people of Hong Kong.

Yu Lik Wai is not the only one experimenting in this fashion. Fruit Chan made his name in 1997 with Made in Hong Kong, one of the first films that depicted life in the poorer sections of the city, in the huge housing projects where $50 \%$ of Hong Kong's residents live. In Durian, Durian, and Little Cheung, he has continued in the same vein, accentuating even further the documentary aspect of his filmmaking. He set up his camera on Portland Street in Mongkok, an old quarter in the heart of Kowloon, which stretches along the continent facing the island of Hong Kong and where most residents of Hong Kong live. Mongkok is a slightly dilapidated neighbourhood that comes alive after dark with its busy night markets and its bordellos, its prostitutes and roaming crowds made up mostly of immigrants from the mainland and of Hong Kong's working class. Chan has said, "It seems today that filmmakers cannot allow themselves to ignore how dramatically the social structure of the country has evolved nor leave an entire slice of society which has grown considerably poorer without a voice ${ }^{(10)}$." The poorest members of society suffered the most during the economic crisis and later on during the SARS epidemic. Throughout those years the gap between the rich and the poor increased.

Another film with a pronounced semi-documentary flavour is Spacked Out by Lawrence Ah Mon. It takes place in Tuen Mun, one of the new high-rise developments that are home to between 200,000 and 400,000 people that have sprung up in the New Territories between Kowloon and China, ugly concrete worlds of suspended highways, shopping malls, karaoke bars... Lawrence Ah Mon's film tells the story of five adolescent girls aged 13 to 15 . Born into broken families, they are pitiless, rebellious, heavily made-up Lolitas with red and black fingernails, dressing according to the latest Japanese fashion and clutching the newest model of cell phones who, instead of regularly going to school, often hang out in the streets and the karaoke bars where they attract the lascivious attention of older men with money in their pockets. Drugs, booze and abortions in shabby clinics fill their unfortunate days. Forming gangs, they engage in knife fights in supermarkets. At the same time, in their tiny bedrooms barely big enough for a bunk bed, they collect stuffed animals and Hello Kitty dolls. As we see them break down in tears during moments of loneliness, we are reminded of the fact that, despite the many lurid scenes of their hard lives, they are only 13 or 14 years old, just girls, whose days seem to hold so very little promise in an unforgiving world. Spacked Out is a film whose only glimmer of hope is in the solidarity and friendship between the main characters.
The film depicts, unfortunately, not a fiction but a reality of life in Hong Kong, one usually hidden behind its gleaming façade. All these films share the same intent, of showing a side to life in Hong Kong that is often carefully obscured by the more typical flamboyant representations of the city.

\section{Wong Kar-wai's "Little shanghai"}

No discussion of Hong Kong cinema during this time would be complete without highlighting the phenomenon of Wong Kar-wai who, through the creation of a new style and an original treatment of images, has fashioned a unique vision of Hong Kong, both nostalgic and futuristic, that has raised the city's stature around the world and gone beyond the old images of Suzie Wong and "East meets West." In Chungking Express, he depicts a young and urbane world in the fast lane. "Wong's work," says his collaborator Christopher Doyle, " is rooted in the rhythm and energy of the city...each element adds to the effect: the city lights, the settings, the sounds, the actor's movements... (II)" In the Mood for Love recreates, in a Proustian fashion, the "Little Shanghai" of immigrants to Hong Kong from 1950 to 1960. It is a beautiful love story-but also a film about memory, a trip through an inner world of distant images, which suddenly reappear with a surreal colour that renders them more insistent and with dialogue paired down to the essential. The films was inspired by the work of the elderly Hong Kong writer, Liu Yichang, another immigrant from Shanghai, whose novel, Intersection (Tête-Bêche/Duidao), helped form the omnipresent image in Wong's films of an intimate, organic Hong Kong, a city of cramped streets and alleys, of naked light bulbs, of multiple clocks ticking off time, and hidden neighbourhoods at the base of skyscrapers where, as Wong Kar-wai said already in 1999, "most people are just passers-by ${ }^{(12) . "}$

\section{Celebrating artists: the new places for art}

The years that followed the return of Hong Kong to China were not easy ones for the people of Hong Kong. After a

10. Olivier Joyard, "Fruit Chan: Hong Kong est réel," Les Cahiers du cinema, Hors Série Cinéma chinois, 1999, pp. 26-29.

11. Erwan Higuinen and Olivier Joyard, "Christopher Doyle, tout contre la camera," Les Cahiers du cinema, ibid., p. 30

12. "Wong Kar-wai "L'architecture et le vampire," Les Cahiers du cinema, Hors Série Cinéma chinois, 1999, pp. 26-29. 


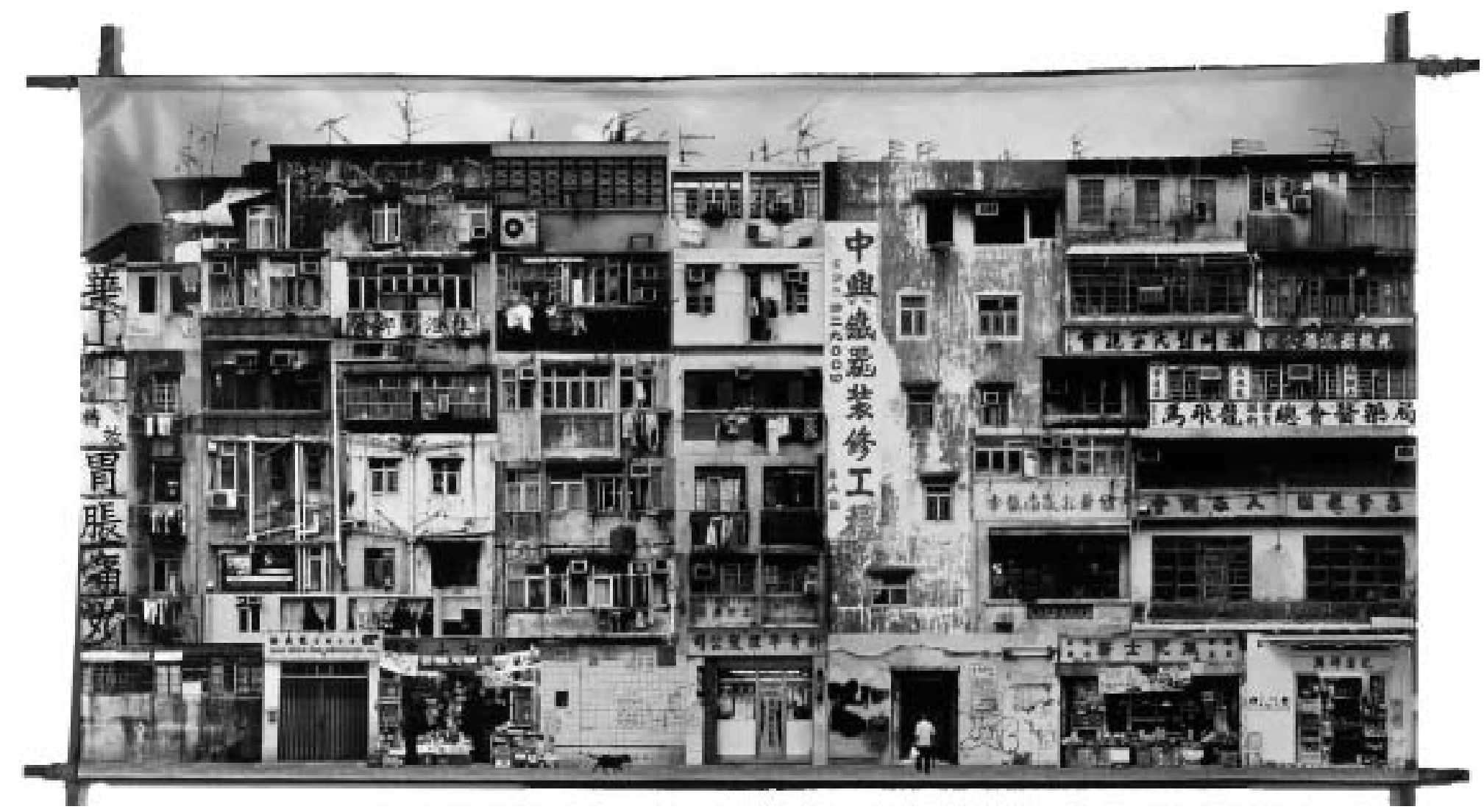

Yau Wan Kei, Old Buildings, 2005

sad and muggy summer in 1997, as if the sign of a kind of post-partum depression, the city plunged into a series of major and minor catastrophes. With the Asian financial crisis, a string of rumours provoked a sense of psychological instability, symbolised by the desperate attempts by thousands of former customers to redeem their gift certificates from a chain of pastry shops that had gone bankrupt by grabbing the remaining loaves of bread, cookies, birthday cakes and even candles. Bird flu came next and made eating the city's favourite dish a health risk. Then came Mickey Mouse, his eyes, as caricatured by Zunzi, sparkling with dollars, a new competitor for the Great Buddha on the Island of Lantau, an enticing alternative to the "Asian values" promoted by the government. The legislative elections of 1998 brought hope then deception, followed by the threat, in 2002, of the anti-subversion law, and then the terrible SARS epidemic of 2003 during which, for several months, Hong Kong was practically cut off from the world. All of these difficult events, however, contributed to a growing sense of solidarity.

As in previous generations, young artists threw themselves into the various struggles that marked this period, even if their work carries few visible traces. In cultural terms, this troubled time was a period of great creativity and expansion. There was, first of all, a multiplication of artistic spaces. At the state level, the opening of the much anticipated Heritage Museum in Shatin brought a new angle to the ambiguous question of Hong Kong's past-some people questioned the justification for building a museum when, at the same time, the state was allowing promoters to destroy large parts of the city's living cultural heritage. More unanimously celebrated was the opening of the Hong Kong Film Archive, the fruit of an enormous collective effort to gather and archive material from the earliest days of the Hong Kong and Chinese film industries.

The plunge in rents triggered by the economic crisis and the exodus of factories towards the mainland created new conditions that made it possible for individual artists and for theatre companies to occupy new spaces. One such location, Oil Street, was particularly festive and innovative. In 1998, the government temporarily rented out to artists an enormous warehouse along the harbour in North Point. Individual artists, art associations, theatre companies, architects, designers, photographers, video artists, and galleries flocked to the site, which became the kind of lively, creative 
and festive environment that had never existed before in Hong Kong. Among the groups of artists were 1 Aspace, Artists Commune, Videotage, Zuni Icosahedron, On and On Theatre, all of which have remained active on the Hong Kong art scene since that time. Today there are hundreds of studios installed in industrial zones, with the greatest concentration in the neighbourhoods of Foshan, Chai Wan, Aberdeen and Kwun Tong. Artists in these neighbourhoods organise annual open studio days to display their work. At the same time there has been a smaller growth in the number of commercial galleries. Most of them sell decorative art. Others, like Hanart TZ, Plum Blossoms, Alisan Fine Arts concentrate on the mainland and overseas Chinese. A few rare exceptions like John Batten Gallery, Grotto Fine Art Gallery and brand new galleries like Too Art work with young Hong Kong artists. The market for contemporary art remains limited: today there are only about sixty commercial galleries, of which less than ten deal in contemporary art from Hong Kong.

\section{In search of a collective memory, Hong Kong affirms its identity}

Has Hong Kong grown closer to China? Do the young in Hong Kong feel that they are part of one country? In the art world, contact with China has increased in the last five years; the development of contemporary Asian art throughout the region has created multiple opportunities, notably with the growth in contemporary art biennales (Shanghai, Guangdong, Beijing, Taiwan, Pusan, Sydney) that have become veritable platforms for meetings and exchanges. Artists from the mainland also travel regularly to Hong Kong and the formation of various art associations has resulted in a network of unofficial exchange and co-operation. Places like the Cattle Depot Artist Village organise several exhibits with artists from the mainland and places like Dashanzi in Beijing and Moganshan Lu in Shanghai are familiar spots to artists from Hong Kong who, previously barely known outside the city, are now invited to practically all the international biennales and exhibits.

Hong Kong sponsors a growing number of international colloquia and seminars on cultural subjects and has become, with the recent creation of the Asia Art Archives, the primary centre of documentation of contemporary art in Asia. Created through the private initiative of a young art historian, Claire $\mathrm{Hsu}$, the AAA is unique in the world with its collection of all the visual and aural documents of contemporary Asian art. A veritable centre of research, the institution is growing rapidly and playing a greater and greater role in attracting artists, researchers and critics from around the globe. Hong Kong's cultural offerings are increasing and the city is sponsoring a growing number of art, film, dance, theatre and music festivals as it becomes without a doubt one of the most open cities in the region, considerably more open than Beijing or Shanghai. At the same time, there continues to be a need to support and encourage local artistic production.

The various exhibits in Hong Kong's pavilion at the Venice Biennale have reflected these tendencies: in 2001, Magic at Street Level emphasised the vivacity of the new urban spaces particular to Hong Kong; in 2005 the exhibit, "Investigation of a journey to the west by micro+polo" featured a city suspended upside down in the air and reconstituted in the famous blue, white and red plastic canvas a tea house, to underscore the origin of popular culture in Hong Kong. In 2007, the specificity of Hong Kong is once again on display with a part of the exhibit created by Mapoffice around the concept of an entirely man-made private island which moves from tropical jungle to concrete jungle until it ends up as a desert of particles or empty shells. In the course of the Biennale the island will move towards the pavilion.

The majority of the projects discussed above have been private initiatives. In the eyes of many professionals the government remains too uninvolved. The system of museums, its heavy administrative machinery, has evolved very slowly and has yet to get in sync with the new cultural developments throughout the wider region. This structural handicap gets in the way of the new teams of conservators who are eager to implicate themselves more in the current dynamic of contemporary art. Until very recently, their internal organisation limited their possibilities for significant contact with the rest of the world. The Hong Kong Biennale, the oldest in the region, remained a competition for local art and never managed to go international, while, at the same time, several modern and contemporary art museums and cultural centres opened up in China and elsewhere in Asia, in some cases, with the support of patrons from Hong Kong. The city has no contemporary art museum, no museum of photography, nor an architecture centre or a multicultural space worthy of the city.

The biggest failure is the stalled project to transform West Kowloon into a cultural quarter. Conceived as part of a government policy to make Hong Kong a world-class cultural city, it is supposed to extend over 100 acres and include an ensemble of cultural facilities, museums, theatres and exhibit spaces. In 2002, Norman Foster won the architectural competition for the project. An enormous glass ceiling would 


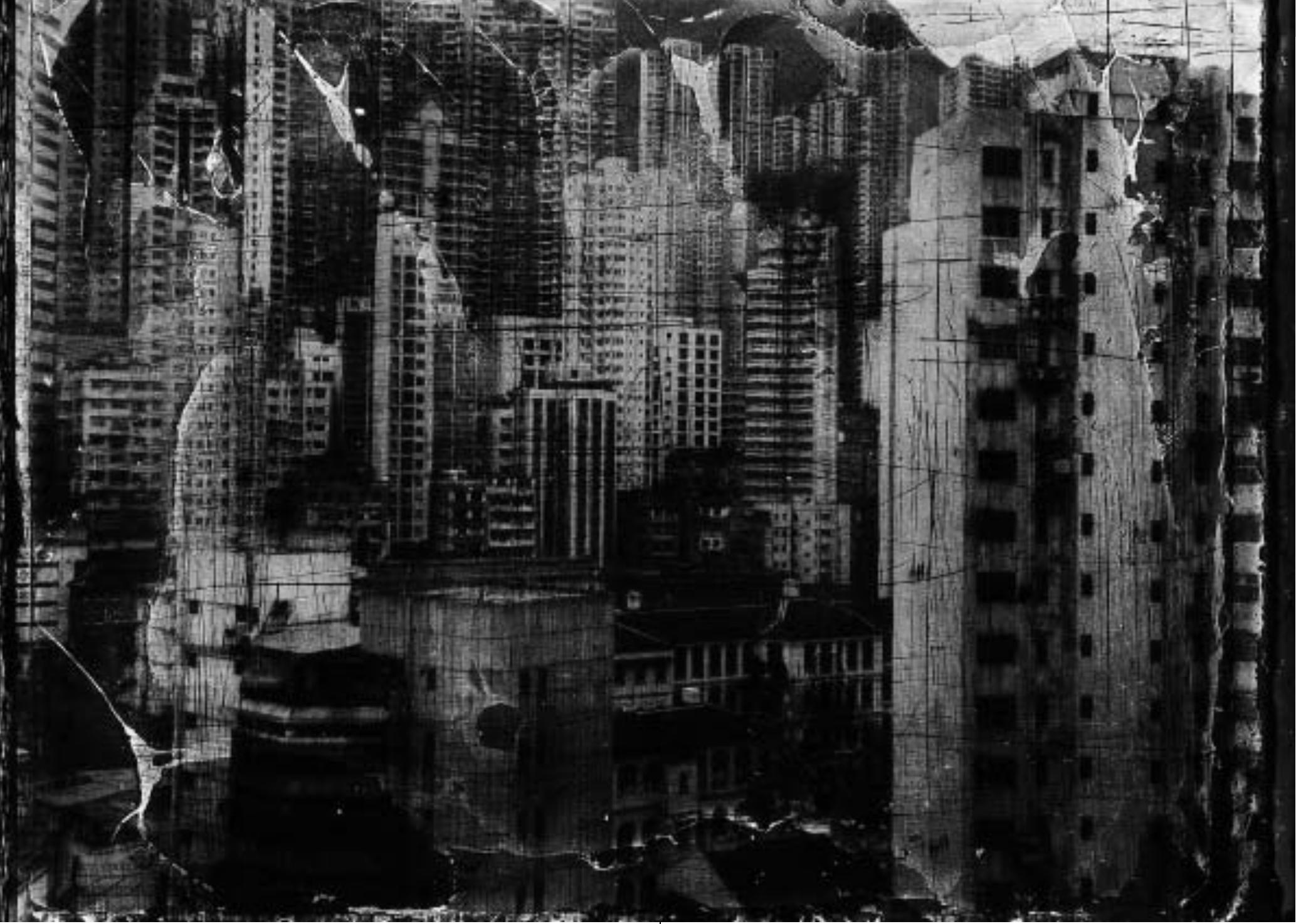

So Hing Keung, Central, 1997

cover an entire quarter that remains to be defined. More thought has gone into the setting than the content. The government's plan was to open bidding to give the entire project to one real estate developer who would offset the construction and management costs by building commercial and residential buildings. The developers that put in a bid, recognising their lack of experience with cultural facilities, turned to foreign organisations like the Pompidou Centre or the Guggenheim for assistance. Public opposition was so great, particularly to the idea of giving the entire contract to a single developer, that the government had to back down and rethink the whole project. The concerns of cultural circles in Hong Kong were also overlooked and the recourse to foreign partners to create a complex that failed to correspond to the perceived needs of those circles was an added affront. A more representative committee is currently reviewing the West Kowloon project, which remains a major undertaking but one that is far from completion.

Curiously, during the last ten years, the attempts by Beijing and the government in Hong Kong to stir up patriotism has had the effect of strengthening a sense of a specific Hong Kong identity. In cultural terms, China has drifted more towards Hong Kong than the other way around. Hong Kongers feel more assured, more self-confident. Students and artists are the avant-garde of a movement to protect their cultural heritage and denounce developers who, in their eagerness for a quick profit, are destroying the last traces of the past. The younger generation of Hong Kongers, born in the city, has discovered the remnants of a collective memory. They criticise the older generation for having allowed it to be liquidated. When, at the beginning of 2007, the government destroyed the Star Ferry in order to build a highway, their adamant opposition triggered a fundamental debate about the future. Picked up on by the press, the debate has captured the interest of the authorities, who have begun to realise that, in order to construct its future, a society must preserve its collective memory, history and common experience; for these are the things that give people a sense of stability, security and belonging?these are the things that define identity. $\bullet$ 